\title{
Production and Characterization of Amorphous Silica Nanoparticles from Coconut Shell and Coir
}

\author{
Dillip Kumar Pattanayak 1,*(D), Jeebanjyoti Muduli 1, Subhendu Sekhar Sahu 1, Susmita Gouda 1, Sujit \\ Meher ${ }^{1}$, Truptimaya Dash ${ }^{1}$, Sambit Rout ${ }^{1}$, Prakash Kumar Pattnaik ${ }^{1}$ \\ 1 Department of Physics (School of Science), GIET University, Gunupur, Rayagada, Odisha-765022, India; \\ dk12phy@gmail.com (D.K.P.), jeebanjyoti199@gmail.com (J.M.), $\quad$ sahu2011ssb@gmail.com (S.S.S.), \\ susmitagouda444@gmail.com (S.G.), sujitmeher21@gmail.com (S.M.), dashtruptimaya@gmail.com (T.D.), \\ s67011133@gmail.com (S.R.), prakashkumarpattnaik@giet.edu (P.K.P.); \\ * Correspondence: dk12phy@gmail.com;
}

Scopus Author ID 56244023200

Received: 26.07.2021; Revised: 2.09.2021; Accepted: 7.09.2021; Published: 30.10.2021

\begin{abstract}
Silica has been produced from coconut coir and coconut shell because of the economic importance of coconut in India. The wastes are generated and disposed of indiscriminately while several are utilized for the energy source. The ash produced by burning them is usually discarded with a considerable amount of extractable silica present. Therefore, extraction of this silica was done using an environmentally friendly chemical approach to produce silica that could be used in several applications. The wastes were calcined at $700^{\circ} \mathrm{C}$ in a muffle furnace to get ash, treated with $\mathrm{HCl}$ to remove soluble metallic oxides, and after that sol-gelled to obtain silica gel. The gel was then dried at $65^{\circ} \mathrm{C}$ for 24 hours and characterized using SEM, EDX, FT-IR, and XRD. Silica produced is amorphous with good absorbance potentials. The SEM micrographs show the particles in the Nano size range but with a high level of agglomeration.
\end{abstract}

Keywords: coconut coir; coconut shell; agricultural wastes; silica; sol-gel.

(C) 2021 by the authors. This article is an open-access article distributed under the terms and conditions of the Creative Commons Attribution (CC BY) license (https://creativecommons.org/licenses/by/4.0/).

\section{Introduction}

Agricultural wastes have been utilized for the production of several useful materials to reduce their disposal challenges. These wastes are often generated and disposed of indiscriminately or burnt, which results in environmental pollution with adverse effects on climate [1]. The side effects of climate have been a major challenge globally because it leads to the death of about 160,000 people annually, according to the World Health Organization (WHO) [2-5]. India utilized $78 \%$ of its landmass, about 2,564,065 square kilometers, to produce several agricultural products and ranked third in eggs, oranges, coconuts, tomatoes, peas, and beans [6]. Literature has shown that agricultural wastes have been used as solid fuel briquettes, adsorbents, cellulose, activated carbon, silica, silicon, refectory, ceramic products, livestock feed, inhibitors, biofuels, construction materials, lignin, and composite reinforcement [7-22]. Silica has been utilized for several applications across industries such as pharmaceuticals, archeology, biomedical, electronics, and silicon feedstock (birth of semiconductor revolution) [23]. It has been used as an intensive blue light emitter, fining agent in the food industry, powder flow agent in the pharmaceutical industry, extra-terrestrial particles collectors, DNA and RNA extractors, and hard abrasives in toothpaste, desiccant, capacitors, and silicon production [24-34]. 
Silica occurs naturally as quartz with the largest percentage in the earth's crust. It is crystalline in nature with low reactivity. Amorphous silica, on the other hand, finds applications in many areas owing to its advantage of being highly reactive. The non-crystalline type has been synthesized from sodium silicate [35], water glass [36, 37], tetraethoxylsilane (TEOS) [38- 40]. It has also been produced from agricultural wastes [19, 34, 41-43, 69, 73] using several methods as reported in reviews $[44,45$, ]. It is usually prepared by reacting sodium carbonate powder and quartz sand at high temperatures to form sodium silicate, which will then react with sulphuric acid to precipitate silica [46]. The methods used for synthesis from agricultural wastes involve a combination of processes like acid treatment, partial burning (charring), burning, calcination, leaching, enzymatic treatment [47], pyrolysis, hydrolysis, and sol-gel [48, 49].

Among wastes generated in India, coconut wastes stand out because they liter our farmlands, residential and industrial areas because of coconut flesh/juice's economic and social importance. Coconut is a fruit of an Arecaceae plant (palm family) and can be found everywhere across India. India accounts for more than $11 \%$ of the total world production after Indonesia and the Philippines [50]. The fruit is $55 \%$ coir, $15 \%$ shell, and $30 \%$ flesh (meat) and juice [51]. The main part is the meat, where coconut oil and meals are produced. The coir (fibrous part) has been found to be useful for mats, ropes, sacks, door mats, brushes, boat caulks, compost, and fiber for mattresses $[50,52]$. Both coir and shell are used as fuels with/without carbon enrichment $[50,53]$. With all this utilization, several coir and shells are domestically disposed of indiscriminately. The ash obtained from both contains a huge amount of silica which can be extracted using simple methods [54,].

In this present work, coconut shell and coir have been used to synthesize amorphous silica using calcination and then sol-gel approach.

\section{Materials and Methods}

\subsection{Materials.}

Coconut fruits were obtained from Karunya University farm settlement, Karunya Nagar, Coimbatore, India. All reagents used are analytical grades (NICE Chemicals Ltd., Kerala, India).

\subsection{Methods.}

The procedure used in this work is as highlighted in Figure 1. This procedure involves separating the coir and shell from the main fruit, removing moisture, volatile matter, and carbon to get ash. This is followed by acid treatment to remove soluble oxides of some metals. The sol-gel involves the formation of silicate solution (solation) from ash (see equation 1) and neutralization of the alkaline solution (gelation) to precipitate silica gel ((see equation 2) dispersed in a sodium hydroxide solution. The centrifuge is carried out to separate the silica from the salt solution with washing and to rinse with double distilled water (DDW) to remove $\mathrm{NaCl}$.

$$
\begin{aligned}
& \mathrm{SiO}_{2}+2 \mathrm{NaOH} \rightarrow \mathrm{a}_{2} \mathrm{SiO}_{3}+\mathrm{H}_{2} \mathrm{O} \\
& \mathrm{Na}_{2} \mathrm{SiO}_{3}+2 \mathrm{HCl} \rightarrow \mathrm{SiO}_{2}+2 \mathrm{NaCl}+\mathrm{H}_{2} \mathrm{O}
\end{aligned}
$$




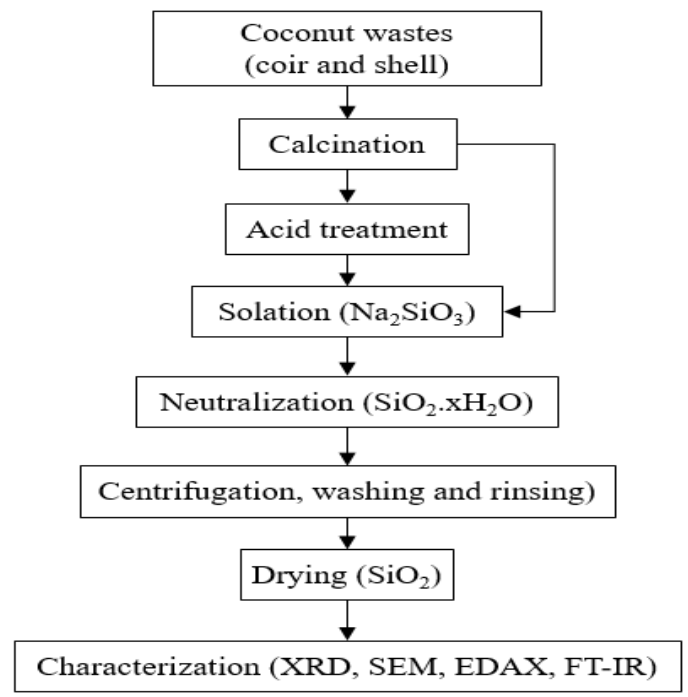

Figure 1. Flow chart of the experimental procedure.

\subsubsection{Preparation of coconut coir and shell ashes.}

15 pieces of coconut fruits were selected and manually separated into coir, shell, and meat. The coir and shells were sun-dried for 14 days before calcination in a muffle furnace. The samples were put in the furnace and then heated at $6^{\circ} \mathrm{C} / \mathrm{min}$ to $700 \mathrm{oC}$. The temperature was held for 3 hours and then off with samples left to cool for 12 hours. Afterward, the samples were removed and labeled as coconut coir ash (CCA) and coconut shell ash (CSA) for coir and shell, respectively.

\subsection{2. production of silica.}

$23 \mathrm{~g}$ of CCA and CSA were leached with $1.0 \mathrm{M} \mathrm{HCl}$ and stirred at $600 \mathrm{rpm}$ for $60 \mathrm{~min}$. Residues were obtained after filtration and rinsing with DDW and then dried in the oven at 105 oC for 24 hours. The dried samples were labeled TCCA and TCSA for CCA and CSA, respectively. For the preparation of sodium silicate from CCA, CSA, TCCA, and TCSA, $12 \mathrm{~g}$ of each were added to $\mathrm{NaOH}$ at $90 \mathrm{oC}$ for $60 \mathrm{~min}$. 3.0 and $1.0 \mathrm{M}$ of $\mathrm{NaOH}$ were used for TCCA and TCSA and 3.0 M for CCA and CSA, respectively. The mixture was allowed to cool and then filtered using Whatman No 1 filter paper. The filtrate was titrated with $1.0 \mathrm{M} \mathrm{HCl}$ until the $\mathrm{pH}$ of 6.0 to ensure the neutralization of the initial $\mathrm{NaOH}$. This is marked with precipitates of silica gel dispersed in the solution below a pH of 10. This was left to age for 18 hours to get clear supernatant and $\mathrm{NaCl}$ solution. The supernatant was decanted, and the remaining silica gel solution was centrifuged at $4000 \mathrm{rpm}$ for $10 \mathrm{mins}$. The supernatant was decanted, and DDW was added for washing. This step was repeated 3 times. The silica gel obtained was then dried in an oven at $65^{\circ} \mathrm{C}$ for 24 hours. The silica obtained was then ground for characterization.

\subsubsection{Characterization}

Silica produced from CCA, CSA, TCCAs and TCSAs were characterized with SEM, EDX, XRD, and FT-IR. SEM was carried out to investigate the morphology and sizes of the silica. EDX was carried out to investigate the chemical composition and invariably the purity of the silica. XRD was to determine the structure of the prepared silica, while FT-IR investigation was carried out to know the functional groups present. 


\section{Results and Discussion}

Figure 2 (a) shows that acid treatment of CCA removed some crystalline phases of metallic oxides marked by disappearance or reduction of crystalline peaks at diffraction angles 27, 41, 50, 58, 63, and 78. This is similar to what is observed in Figure 2 (b) but with some insoluble phases present in treated coconut shell ash. The leaching efficacy of the acid is observed in both coconut coir and shell ashes. This procedure has been reported to be effective for obtaining pure silica [55]. The presence of amorphous silica, which is extractable can, is observed in both the treated and untreated coconut coir and shell ashes. This spread is located between the angle of diffractions 15 and $40^{\circ}[56$,
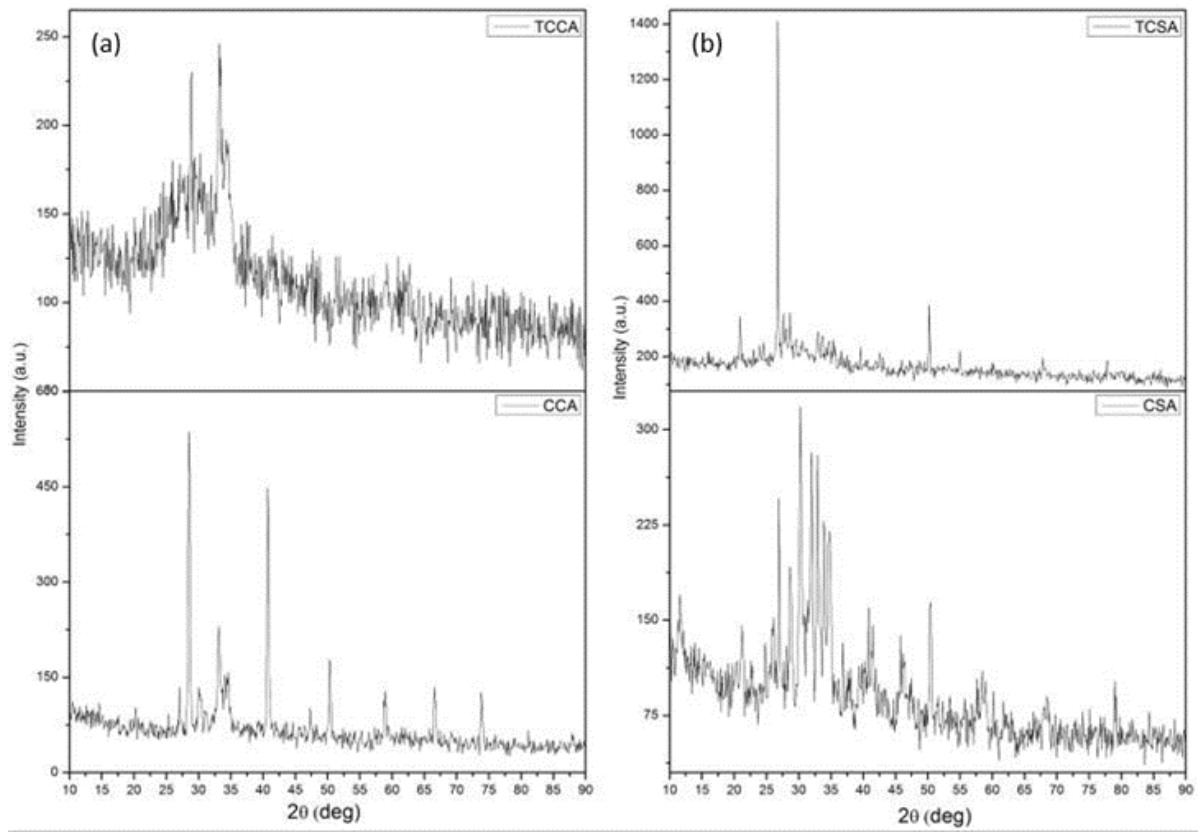

Figure 2. Effect of acid treatment on CCA and CSA.

The amorphous nature of silica produced from both the coir and shell with/without treatments is shown in Figure 3. The crystalline peaks from Figure 3 (a) and Figure 3 (b-UCSA) are unwashed $\mathrm{NaCl}$ from the solution. The peaks are found to correspond to JCPDS card nos: 78-0751 and 01-0994. The sodium chloride, as given in equation 2 is due to the neutralization of $\mathrm{NaOH}$ reagent used for solation by $\mathrm{HCl}$. This phase can be removed using hot water washing and rinsing that has been reported to be effective for removing any traces of $\mathrm{NaCl}$ [56]. Table 1 shows the chemical compositions of silica obtained through the various approaches. The major impurity in the silica obtained is aluminum $\left(\right.$ as $\left.\mathrm{Al}_{2} \mathrm{O}_{3}\right)$ which is an amphoteric oxide. This forms precipitates when leached with acid and soluble hydroxide when treated with base. Using a weak base for the solation of CCA yields silica free of aluminum, while it seems difficult for CSA. Hence, the removal of this oxide is a concern. The $\mathrm{Na}$ and $\mathrm{Cl}$ present can be removed by hot water washing or repeated washing of the silica gel until free of the salt. Figure 4 shows that all the silica produced is below $100 \mathrm{~nm}$. This is due to the method used, which is categorized as an appropriate approach to the synthesis of nanoparticles categorized as a bottom-up approach in the review of Adebisi, Agunsoye [44]. The micrographs also show that there is agglomeration in the procedure used. 

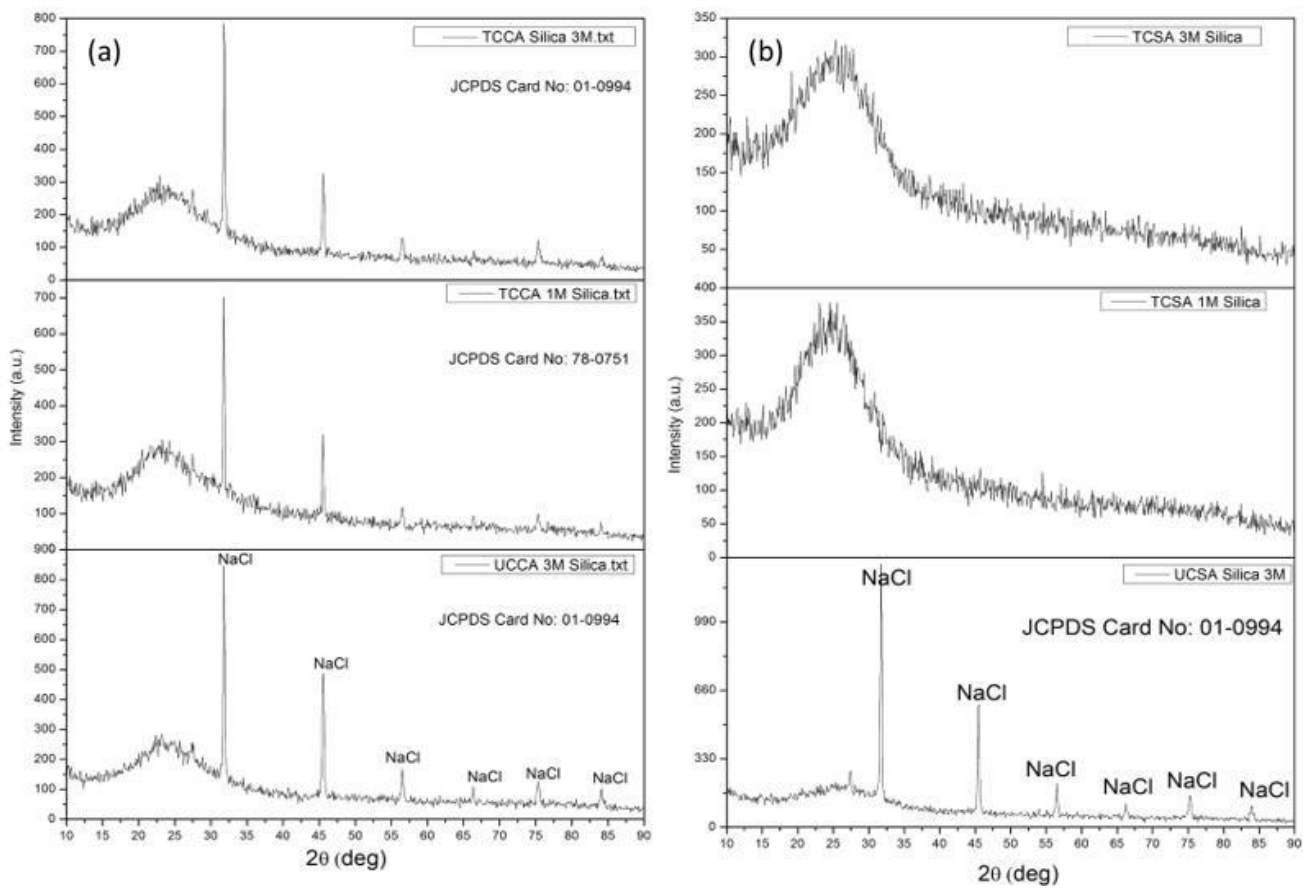

Figure 3. Silica produced from CCA, TCCA, CSA, and TCSA.

Table 1. Chemical composition of silica produced.

\begin{tabular}{l|c|c|c|c|c|c}
\multirow{2}{*}{ Elements } & \multicolumn{7}{|c}{ Composition of silica (wt. \%) } \\
\cline { 2 - 7 } & UCCA 3M & TCCA 1M & TCCA 3M & UCSA 3M & TCSA 1M & TCSA 3M \\
\hline $\mathrm{O}$ & 54.04 & 45.3 & 57.14 & 56.34 & 64.49 & 54.33 \\
\hline $\mathrm{Na}$ & 4.31 & 8.76 & 3.37 & 4.13 & & \\
\hline $\mathrm{Al}$ & 2.82 & & 2.51 & 6.12 & 19.78 & 5.11 \\
\hline $\mathrm{Si}$ & 31.33 & 32.57 & 32.43 & 24.62 & 15.73 & 40.56 \\
\hline $\mathrm{Cl}$ & 5.57 & 11.7 & 3.46 & 3.61 & & \\
\hline $\mathrm{K}$ & 1.93 & 1.67 & 1.09 & 5.19 & &
\end{tabular}

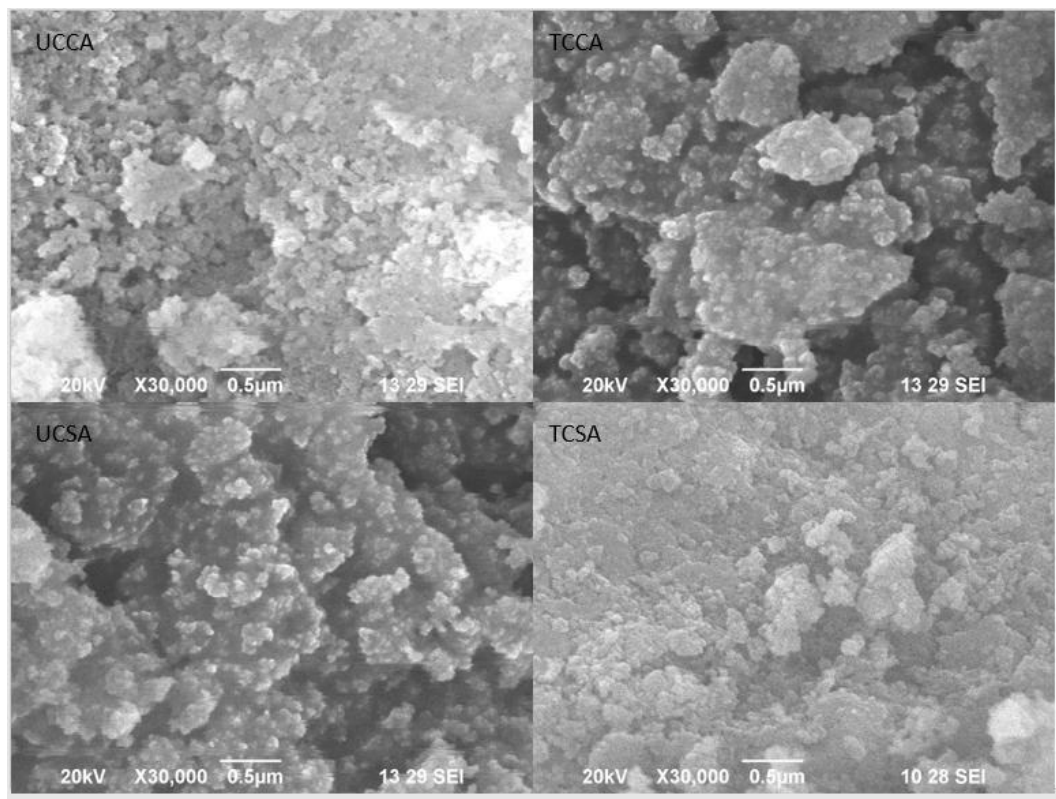

Figure 4. SEM micrographs for untreated and treated coconut coir and shell silica.

The FT-IR spectrum of silica produced from the coir and shell is shown in Figure 5. Silica is characterized by band between 400 and $1300 \mathrm{~cm}^{-1}[42,55,57-66]$. The spectra from prepared silica exhibit bands at 448, 796, and $1085 \mathrm{~cm}^{-1}$, corresponding to characteristics rocking of the $\mathrm{Si}-\mathrm{O}$ bond, bending, and symmetric and asymmetric stretching of the Si-O-Si bond, respectively [42]. Drying the samples at $65 \mathrm{oC}$ left the samples with $\mathrm{OH}$ and $\mathrm{H}-\mathrm{O}-\mathrm{H}$ 
bonds for silanol and adsorbed water [57]. The band at $1642 \mathrm{~cm}^{-1}$ corresponds to $\mathrm{H}-\mathrm{O}-\mathrm{H}$ twisting. The band spreading from 2600 to $3800 \mathrm{~cm}^{-1}$ represents stretching vibrations of the surface silanols $(\mathrm{Si}-\mathrm{OH})$ groups excited by hydrogen bonds of either water adsorbed or those between Si-O molecules [55, 57, ]. The high transmittance values of silica obtained from the untreated samples (CCA and CSA) translate low absorbance compared to those from treated samples. This characteristic high peak of the untreated samples has been reported by Carmona, Oliveira [57, 67-71].

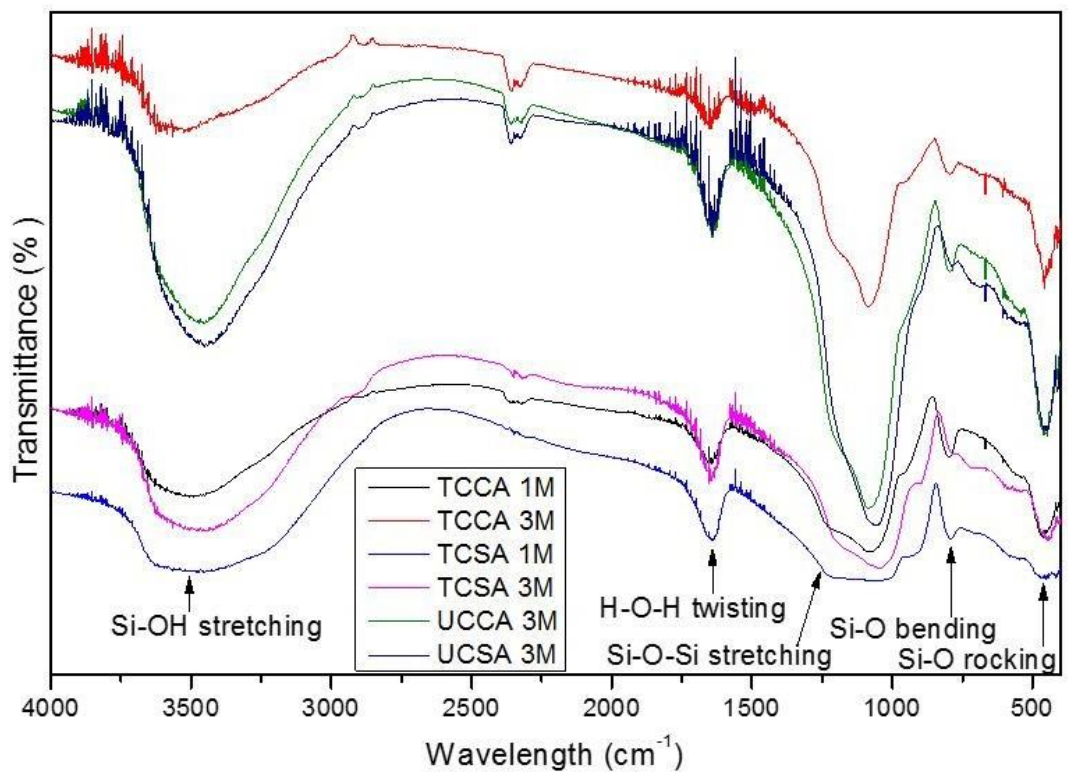

Figure 5. Infrared bands of prepared silica.

\section{Conclusions}

Silica nanoparticle has been produced from coconut wastes using simple chemical methods. Acid treatment of the ashes is effective for the removal of metallic impurities. It also activates the bonds of both coir and shell samples with good absorbance properties, as inferred from the FT-IR spectrum. Impurities observed in the silica from EDX are Al and $\mathrm{K}$ but residual $\mathrm{Na}$ and $\mathrm{Cl}$ from the titration procedure. The silica particles produced are less than $100 \mathrm{~nm}$ but highly agglomerated due to high attraction between the $\mathrm{Si}-\mathrm{O}$ and $\mathrm{Si}-\mathrm{OH}$ bonds. XRD results show the silica from both the coir and shell of coconut are amorphous.

\section{Funding}

This research received no external funding.

\section{Acknowledgments}

The authors acknowledge Karunya University for technical support.

\section{Conflicts of Interest}

The authors declare no conflict of interest.

\section{References}

1. Key World Energy Statistics 2020 available online: https://www.iea.org/reports/key-world-energy-statistics2020 (Accesed date: 5.02.2021). 
2. White, J.W.C.; Alley, R.B.; Archer, D.E.; Barnosky, A.D.; Dunlea, E.; Foley, J.; Fu, R.; Holland, M.M.; Lozier, M.S.; Schmitt, J. Abrupt Impacts of Climate Change: Anticipating Surprises. National Academic Press: Washington DC, USA, 2013; pp. 87-92, https://doi.org/10.17226/18373.

3. Mcnutt, M.K. Climate Intervention. 1st ed; National Academic Press: Washington DC, USA, 2015; pp. 5467, https://doi.org/10.17226/18805.

4. Mcnutt, M.K. Frontiers in Understanding Climate Change and Polar Ecosystems. National Academic Press: Washington DC, USA, 2011; pp. 51-67, https://doi.org/10.17226/13132.

5. Asif, M.; Muneer, T. Energy supply, its demand and security issues for developed and emerging economies. Renewable and Sustainable Energy Reviews 2007, 11, 1388-1413, https://doi.org/10.1016/j.rser.2005.12.004.

6. FAO available from http://faostat.fao.org/ (05-02-2021).

7. Nadzri, S.N.I.H.A.; Sultan, M.T.H.; Shah, A.U.M.; Safri, S.N.A.; Talib, A.R.A.; Jawaid, M.; Basri, A.A. A comprehensive review of coconut shell powder composites: Preparation, processing, and characterization. Journal of Thermoplastic Composite Materials 2020, https://doi.org/10.1177/0892705720930808.

8. Agunsoye, J.O.; Bello, S.A.; Adetola, L.O. Experimental investigation and theoretical prediction of tensile properties of Delonix regia seed particle reinforced polymeric composites. Journal of King Saud University - Engineering Sciences 2019, 31, 70-77, https://doi.org/10.1016/j.jksues.2017.01.005.

9. Emmanuel, A.E.-O.; Frank, A.I. Prolonged Curing of Green Concrete from Domestically Derived Cassava Peels Ash (DDCPA) and Laterite. Int J Sci Eng Res. 2014, 5, 900-905.

10. Feedipedia. Available online https://www.feedipedia.org/node/526 (Accesed date: 24.02.2021).

11. Aigbodion, V.; Hassan, S.; Ause, T.; Nyior, G.J.J.o.M.; Characterization, M.; Engineering. Potential utilization of solid waste (bagasse ash) $J$ Miner Mater Charact Eng. 2010, 9, 67-77, https://doi.org/10.4236/jmmce.2010.91006.

12. Kalderis, D.; Bethanis, S.; Paraskeva, P.; Diamadopoulos, E. Production of activated carbon from bagasse and rice husk by a single-stage chemical activation method at low retention times. Bioresource Technology 2008, 99, 6809-6816, https://doi.org/10.1016/j.biortech.2008.01.041.

13. Olajide, J.O.; Afolabi, T.J.; Adeniran, J.A.J.I.J.E. Optimization of oil yield from shea kernels using response surface methodology and adaptive Neuro Fuzzy inference system (ANFIS). Int J Eng Res Technol. 2014, 3, 1611-1620.

14. Kurniawan, A.; Kosasih, A.N.; Febrianto, J.; Ju, Y.-H.; Sunarso, J.; Indraswati, N.; Ismadji, S. Evaluation of cassava peel waste as lowcost biosorbent for Ni-sorption: Equilibrium, kinetics, thermodynamics and mechanism. Chemical Engineering Journal 2011, 172, 158-166, https://doi.org/10.1016/j.cej.2011.05.083.

15. Ki, O.L.; Kurniawan, A.; Lin, C.X.; Ju, Y.-H.; Ismadji, S. Bio-oil from cassava peel: A potential renewable energy source. Bioresource Technology 2013, 145, 157-161, https://doi.org/10.1016/j.biortech.2013.01.122.

16. Liu, Z.; Quek, A.; Balasubramanian, R. Preparation and characterization of fuel pellets from woody biomass, agro-residues and their corresponding hydrochars. Applied Energy 2014, 113, 1315-1322, https://doi.org/10.1016/j.apenergy.2013.08.087.

17. Odusote, J.; Owalude, D.; J. Olusegun, S.; Abolore, Y. Inhibition Efficiency of Moringa Oleifera Leaf Extract on the Corrosion of Reinforced Steel Bar in $\mathrm{HCl}$ Solution. The West Indian J. Eng. 2016, 38.

18. Achinivu, E.C.; Howard, R.M.; Li, G.; Gracz, H.; Henderson, W.A. Lignin extraction from biomass with protic ionic liquids. Green Chemistry 2014, 16, 1114-1119, https://doi.org/10.1039/c3gc42306a.

19. Adebisi, J.; Agunsoye, J.; Bello, S.; Haris, M.; Ramakokovhu, M.; Daramola, M.; Hassan, S.J.N.J.O.T.D. Extraction of silica from cassava periderm using modified sol-gel method. Niger J Technol Dev. 2018, 15, https://doi.org/10.4314/njtd.v15i2.4.

20. Fu, D.; Mazza, G.; Tamaki, Y. Lignin Extraction from Straw by Ionic Liquids and Enzymatic Hydrolysis of the Cellulosic Residues. Journal of Agricultural and Food Chemistry 2010, 58, 2915-2922, https://doi.org/10.1021/jf903616y.

21. Venkateswaran, S.; Yuvakkumar, R.; Rajendran, V. Nano Silicon from Nano Silica Using Natural Resource (Rha) for Solar Cell Fabrication. Phosphorus, Sulfur, and Silicon and the Related Elements 2013, 188, 11781193, https://doi.org/10.1080/10426507.2012.740106.

22. Le Normand, M.; Moriana, R.; Ek, M. Isolation and characterization of cellulose nanocrystals from spruce bark in a biorefinery perspective. Carbohydrate Polymers 2014, 111, 979-987, https://doi.org/10.1016/j.carbpol.2014.04.092.

23. Wikipedia.Available online https://en.m.wikipedia.org/wiki/Silicon_dioxide (23.02.2021).

24. Yu, D.P.; Hang, Q.L.; Ding, Y.; Zhang, H.Z.; Bai, Z.G.; Wang, J.J.; Zou, Y.H.; Qian, W.; Xiong, G.C.; Feng, S.Q. Amorphous silica nanowires: Intensive blue light emitters. Applied Physics Letters 1998, 73, 3076-3078, https://doi.org/10.1063/1.122677.

25. Castellari, M.; Versari, A.; Fabiani, A.; Parpinello, G.P.; Galassi, S. Removal of Ochratoxin A in Red Wines by Means of Adsorption Treatments with Commercial Fining Agents. Journal of Agricultural and Food Chemistry 2001, 49, 3917-3921, https://doi.org/10.1021/jf010137o.

26. Forny, L.; Pezron, I.; Saleh, K.; Guigon, P.; Komunjer, L. Storing water in powder form by self-assembling hydrophobic silica nanoparticles. Powder Technology 2007, $171, \quad$ 15-24, https://doi.org/10.1016/j.powtec.2006.09.006. 
27. Chattoraj, S.; Shi, L.; Sun, C.C. Profoundly improving flow properties of a cohesive cellulose powder by surface coating with nano-silica through comilling. Journal of Pharmaceutical Sciences 2011, 100, 49434952, https://doi.org/10.1002/jps.22677.

28. Westphal, A.J.; Bechtel, H.A.; Brenker, F.E.; Butterworth, A.L.; Flynn, G.; Frank, D.R.; Gainsforth, Z.; Hillier, J.K.; Postberg, F.; Simionovici, A.S.; Sterken, V.J.; Stroud, R.M.; Allen, C.; Anderson, D.; Ansari, A.; Bajt, S.; Bastien, R.K.; Bassim, N.; Borg, J.; Bridges, J.; Brownlee, D.E.; Burchell, M.; Burghammer, M.; Changela, H.; Cloetens, P.; Davis, A.M.; Doll, R.; Floss, C.; Grün, E.; Heck, P.R.; Hoppe, P.; Hudson, B.; Huth, J.; Hvide, B.; Kearsley, A.; King, A.J.; Lai, B.; Leitner, J.; Lemelle, L.; Leroux, H.; Leonard, A.; Lettieri, R.; Marchant, W.; Nittler, L.R.; Ogliore, R.; Ong, W.J.; Price, M.C.; Sandford, S.A.; Tresseras, J.A.S.; Schmitz, S.; Schoonjans, T.; Silversmit, G.; Solé, V.A.; Srama, R.; Stadermann, F.; Stephan, T.; Stodolna, J.; Sutton, S.; Trieloff, M.; Tsou, P.; Tsuchiyama, A.; Tyliszczak, T.; Vekemans, B.; Vincze, L.; Von Korff, J.; Wordsworth, N.; Zevin, D.; Zolensky, M.E.; dusters, S.h. Final reports of the Stardust Interstellar Preliminary Examination. Meteoritics \& Planetary Science 2014, 49, 1720-1733, https://doi.org/10.1111/maps.12221.

29. Tan, S.C.; Yiap, B.C. DNA, RNA, and Protein Extraction: The Past and The Present. Journal of Biomedicine and Biotechnology 2009, 2009, https://doi.org/10.1155/2009/574398.

30. Joiner, A. A silica toothpaste containing blue covarine: a new technological breakthrough in whitening. International Dental Journal 2009, 59, 284-288, https://doi.org/10.1922/IDJ_2261Joiner05.

31. Joshi Hari, H.; Gertz Robert, E.; da Gloria Carvalho, M.; Beall Bernard, W. Use of Silica Desiccant Packets for Specimen Storage and Transport To Evaluate Pneumococcal Nasopharyngeal Carriage among Nepalese Children. Journal of Clinical Microbiology 2008, 46, 3175-3176, https://doi.org/10.1128/JCM.00906-08.

32. Negre, L.; Daffos, B.; Turq, V.; Taberna, P.L.; Simon, P. Ionogel-based solid-state supercapacitor operating over a wide range of temperature. Electrochimica Acta 2016, 206, 490-495, https://doi.org/10.1016/j.electacta.2016.02.013.

33. Mohammad-Rezaei, R.; Razmi, H. Preparation and Characterization of Reduced Graphene Oxide Doped in Sol-Gel Derived Silica for Application in Electrochemical Double-Layer Capacitors. Int J Nanosci Nanotechnol. 2016, 12, 233-241.

34. Sudirman; Anggaravidya, M.; Budianto, E.; Gunawan, I. Synthesis and Characterization of Polyester-Based Nanocomposite. Procedia Chemistry 2012, 4, 107-113, https://doi.org/10.1016/j.proche.2012.06.016.

35. Mazraeh-Shahi, Z.T.; Shoushtari, A.M.; Bahramian, A.R. A New Method for Measuring the Thermal Insulation Properties of Fibrous Silica Aerogel Composite. Procedia Materials Science 2015, 11, 583-587, https://doi.org/10.1016/j.mspro.2015.11.081.

36. Shi, F.; Wang, L.; Liu, J. Synthesis and characterization of silica aerogels by a novel fast ambient pressure drying process. Materials Letters 2006, 60, 3718-3722, https://doi.org/10.1016/j.matlet.2006.03.095.

37. Lee, S.; Cha, Y.C.; Hwang, H.J.; Moon, J.-W.; Han, I.S. The effect of pH on the physicochemical properties of silica aerogels prepared by an ambient pressure drying method. Materials Letters 2007, 61, 3130-3133, https://doi.org/10.1016/j.matlet.2006.11.010.

38. Shimura, N.; Ogawa, M. Preparation of surfactant templated nanoporous silica spherical particles by the Stöber method. Effect of solvent composition on the particle size. Journal of Materials Science 2007, 42, 5299-5306, https://doi.org/10.1007/s10853-007-1771-y.

39. Liu, Y.; Zhou, H.; Shen, Z.; Li, L.; Zhou, X.; Sun, P.; Yuan, Z.; Chen, T.; Li, B.; Ding, D. Synthesis of nanoporous silica with interior composite cells with synthetic block copolypeptide as template. Chinese Science Bulletin 2006, 51, 493-497, https://doi.org/10.1007/s11434-006-0493-x.

40. He, Z.W.; Liu, X.Q.; Su, Q.; Wang, Y.Y. Improvement of electrical properties of low dielectric constant nanoporous silica films prepared using sol-gel method with catalyst HF. Applied Physics A 2006, 82, 349355, https://doi.org/10.1007/s00339-005-3376-0.

41. Mohanraj, K.; Kannan, S.; Barathan, S.; Sivakumar, G. Preparation and characterization of nano SiO 2 from corn Cob Ash by precipitation method. Optoelectronics and Advanced Materials, Rapid Communications 2012, 6, 394-397.

42. Espíndola-Gonzalez, A.; Martínez-Hernández, A.L.; Angeles-Chávez, C.; Castaño, V.M.; Velasco-Santos, C. Novel Crystalline SiO2 Nanoparticles via Annelids Bioprocessing of Agro-Industrial Wastes. Nanoscale Research Letters 2010, 5, 1408-1417, https://doi.org/10.1007/s11671-010-9654-6.

43. Vaibhav, V.; Vijayalakshmi, U.; Roopan, S.M. Agricultural waste as a source for the production of silica nanoparticles. Spectrochimica Acta Part A: Molecular and Biomolecular Spectroscopy 2015, 139, 515-520, https://doi.org/10.1016/j.saa.2014.12.083.

44. Adebisi, J.A.; Agunsoye, J.O.; Bello, S.A.; Ahmed, I.I.; Ojo, O.A.; Hassan, S.B. Potential of producing solar grade silicon nanoparticles from selected agro-wastes: A review. Solar Energy 2017, 142, 68-86, https://doi.org/10.1016/j.solener.2016.12.001.

45. Chandrasekhar, S.; Satyanarayana, K.G.; Pramada, P.N.; Raghavan, P.; Gupta, T.N. Review Processing, properties and applications of reactive silica from rice husk - an overview. Journal of Materials Science 2003, 38, 3159-3168, https://doi.org/10.1023/A:1025157114800. 
46. Soltani, N.; Bahrami, A.; Pech-Canul, M.I.; González, L.A. Review on the physicochemical treatments of rice husk for production of advanced materials. Chemical Engineering Journal 2015, 264, 899-935, https://doi.org/10.1016/j.cej.2014.11.056.

47. Decker, S.R.; Sheehan, J.; Dayton, D.C.; Bozell, J.J.; Adney, W.S.; Hames, B.; Thomas, S.R.; Bain, R.L.; Czernik, S.; Zhang, M.; Himmel, M.E. Biomass conversion. Handb Ind Chem Biotechnol Twelfth Ed. 2012, 2, 1249-1322, https://doi.org/10.1007/978-1-4614-4259-2_33.

48. Nayak, J.P.; Bera, J. Bioactivity Characterization of Amorphous Silica Ceramics Derived from Rice Husk Ash. Silicon 2012, 4, 57-60, https://doi.org/10.1007/s12633-010-9058-3.

49. Mansha, M.; Syed, H.; Javed, M.; Kazmi, N.; Feroze. Study of Rice Husk Ash as Potential Source of Acid Resistance Calcium Silicate. Advances in Chemical Engineering and Science 2011, 01, 147-153, https://doi.org/10.4236/aces.2011.13022.

50. Bellow, S.A.; Agunsoye, J.O.; Adebisi, J.A.; Kolawole, F.O.; Hassan, S.B. Physical properties of coconut shell nanoparticles. Kathmandu University Journal of Science, Engineering and Technology 2018, 12, 63-79, https://doi.org/10.3126/kuset.v12i1.21566.

51. Coconut palm products: Their processing in developing countries. Available online https://agris.fao.org/agris-search/search.do?recordID=XF19770195614 (Accesed date: 14.02.2021).

52. Supreme Carbon Indonesia. Available from: http://www.supremecarbon.com/charcoal.htm. (Accesed date: 12.02.2021).

53. Sivasubramanian, S.; Sravanthi, K. Synthesis and characterisation of silica nano particles from coconut shell. International Journal of Pharma and Bio Sciences 2015, 6, 530-536.

54. Rafiee, E.; Shahebrahimi, S.; Feyzi, M.; Shaterzadeh, M. Optimization of synthesis and characterization of nanosilica produced from rice husk (a common waste material). International Nano Letters 2012, 2, 1-8, https://doi.org/10.1186/2228-5326-2-29.

55. Yuvakkumar, R.; Nathanael, A.J.; Rajendran, V.; Hong, S.I. Rice husk ash nanosilica to inhibit human breast cancer cell line (3T3). Journal of Sol-Gel Science and Technology 2014, 72, 198-205, https://doi.org/10.1007/s10971-014-3455-9.

56. Carmona, V.B.; Oliveira, R.M.; Silva, W.T.L.; Mattoso, L.H.C.; Marconcini, J.M. Nanosilica from rice husk: Extraction and characterization. Industrial Crops and Products 2013, 43, 291-296, https://doi.org/10.1016/j.indcrop.2012.06.050.

57. Liou, T.-H. Preparation and characterization of nano-structured silica from rice husk. Materials Science and Engineering: A 2004, 364, 313-323, https://doi.org/10.1016/j.msea.2003.08.045.

58. Liou, T.-H.; Yang, C.-C. Synthesis and surface characteristics of nanosilica produced from alkali-extracted rice husk ash. Materials Science and Engineering: $B$ 2011, 176, 521-529, https://doi.org/10.1016/j.mseb.2011.01.007.

59. Singh, J.; Boddula, R.; Digambar Jirimali, H. Utilization of secondary agricultural products for the preparation of value added silica materials and their important applications: a review. Journal of Sol-Gel Science and Technology 2020, 96, 15-33, https://doi.org/10.1007/s10971-020-05353-5.

60. Anuar, M.F.; Fen, Y.W.; Zaid, M.H.M.; Matori, K.A.; Khaidir, R.E.M. Synthesis and structural properties of coconut husk as potential silica source. Results in Physics 2018, 11, 1-4, https://doi.org/10.1016/j.rinp.2018.08.018.

61. Anuar, M.F.; Fen, Y.W.; Zaid, M.H.M.; Omar, N.A.S. Optical studies of crystalline ZnO-SiO2 developed from pyrolysis of coconut husk. Materials Research Express 2020, 7, https://doi.org/10.1088/20531591/ab8a81.

62. Anuar, M.F.; Fen, Y.W.; Zaid, M.H.; Matori, K.A.; Khaidir, R.E. The Physical and Optical Studies of Crystalline Silica Derived from the Green Synthesis of Coconut Husk Ash. Applied Sciences 2020, 10, https://doi.org/10.3390/app10062128.

63. Datkhile, R.; Laad, M.; Ghule, B. Research Trend of Metal Matrix Composites reinforced with silica extracted by green route: A Bibliometric Analysis. Libr Philos Pract. 2021, 1-15.

64. Imoisili, P.E.; Ukoba, K.O.; Jen, T.-C. Synthesis and characterization of amorphous mesoporous silica from palm kernel shell ash. Boletín de la Sociedad Española de Cerámica y Vidrio 2020, 59, 159-164, https://doi.org/10.1016/j.bsecv.2019.09.006.

65. Dhaneswara, D.; Fatriansyah, J.F.; Situmorang, F.W.; Haqoh, A.N. Synthesis of Amorphous Silica from Rice Husk Ash: Comparing $\mathrm{HCl}$ and $\mathrm{CH} 3 \mathrm{COOH}$ Acidification Methods and Various Alkaline Concentrations. Int J Technol. 2020, 11, 200-208, https://doi.org/10.14716/ijtech.v11i1.3335.

66. Zhou, C.; Wang, Y. Recent progress in the conversion of biomass wastes into functional materials for valueadded applications. Science and Technology of Advanced Materials 2020, 21, 787-804, https://doi.org/10.1080/14686996.2020.1848213.

67. Susnik, E.; Taladriz-Blanco, P.; Drasler, B.; Balog, S.; Petri-Fink, A.; Rothen-Rutishauser, B. Increased Uptake of Silica Nanoparticles in Inflamed Macrophages but Not upon Co-Exposure to Micron-Sized Particles. Cells 2020, 9, https://doi.org/10.3390/cells9092099. 
68. Prabha, S.; Durgalakshmi, D.; Rajendran, S.; Lichtfouse, E. Plant-derived silica nanoparticles and composites for biosensors, bioimaging, drug delivery and supercapacitors: a review. Environmental Chemistry Letters 2021, 19, 1667-1691, https://doi.org/10.1007/s10311-020-01123-5.

69. Prabhushankar, N.; Balaji, N. Various Alternative Sources for Silica Sand, Binders and Additives in Sand Casting and their Properties - A Review. IOP Conference Series: Materials Science and Engineering 2020, 993, https://doi.org/10.1088/1757-899X/993/1/012137.

70. Hossain, S.S.; Mathur, L.; Roy, P.K. Rice husk/rice husk ash as an alternative source of silica in ceramics: A review. Journal of Asian Ceramic Societies 2018, 6, 299-313, https://doi.org/10.1080/21870764.2018.1539210.

71. Surayah Osman, N.; Sapawe, N. Waste Material As an Alternative Source of Silica Precursor in Silica Nanoparticle Synthesis - A Review. Materials Today: Proceedings 2019, 19, 1267-1272, https://doi.org/10.1016/j.matpr.2019.11.132. 